\title{
La reconstrucción del Gran Concepción: territorio y catástrofe como permanencia histórica $^{1}$
}

\author{
Enrique Aliste ${ }^{2}$ y Sofía Pérez ${ }^{3}$
}

\begin{abstract}
RESUMEN
Se exploran archivos ministeriales y de prensa para dar cuenta de las narrativas y discursos que acompañan los procesos de reconstrucción posteriores a los desastres derivados de los terremotos de 1939 y 1960. Lo anterior se estudia con la intención de seguir el modo en que la ciudad se va concibiendo desde estos procesos de reconstrucción, viendo la manera en que se llevan adelante con sus similitudes y diferencias. Se logra visualizar la gran semejanza entre los diferentes desastres en materia de acción pública y las narrativas que les acompañan. Aquello que podría llevar a pensar en una fuerte memoria viva del desastre en la ciudad, muestra más bien lo contrario con una tendencia al olvido, situación que podría explicar la permanencia de los procesos de reconstrucción y catástrofe sin una institucionalidad realmente preparada para ello, pese a la existencia de importantes decisiones tomadas en el siglo XX para enfrentarlas.
\end{abstract}

Palabras clave: Terremoto, desastres, geografía histórica, narrativas, memoria.

\begin{abstract}
We explore ministerial and media files to account for the narratives and discourses that accompany the process of reconstruction after disasters resulting from earthquakes in 1939 and 1960. This is explored with the intention of following the way the city will conceive from these processes of reconstruction, seeing how they are carried on with their similarities and differences. It does see the great similarity between the different disasters in terms of public action and the narratives that accompany them. That which might lead one to believe in a strong disaster in living memory of the city, shows quite the opposite with a tendency to forget, and this could explain the persistence of the processes of reconstruction and an institutional disaster without really prepared for it, despite the existence of important decisions made in the twentieth century to address them.
\end{abstract}

Key words: Earthquake, disaster, historical geography, narratives, memory.

1 Artículo realizado gracias a los proyectos FONDECYT 1090248 y 1120306 . Artículo recibido el 7 de junio de 2012, aceptado el 30 de junio de 2012 y corregido el 31 de julio de 2012.
2 Departamento de Geografía, Universidad de Chile (Chile). E-mail: ealiste@uchilefau.cl

3 Máster TEMA, EHESS (Francia) / Charles University of Prague (República Checa). E-mail: sofiaperezh@gmail.com 
"Descorramos por un instante el velo de su pasado y sigamos en sus huellas marcadas en surcos de sangre y de lágrimas, para atalayar su grandeza y vislumbrar su porvenir a la luz de recuerdos no borrados de la triste odisea del martirologio de su historia.

Pues que, a la manera del Hércules mitológico, Concepción se iniciaba en la lucha desde los primeros vagidos de la vida, al abrir sus ojos al mundo y percibir en sus oídos el bullicio de los futuros combates y el estrépito de las borrascas que se desencadenarían en deshecha tempestad, en el proceloso mar de su agitada existencia (...) Los elementos exterminadores de las sangrientas contiendas habían concluido y empezaban las leyes de la naturaleza a conjurarse contra su tranquilidad y su fortuna" (Lara, 1886: 27).

Los párrafos corresponden a la obra de Horacio Lara Marchant La Ciudad Mártir, elocuente título para un ensayo sobre las trágicas circunstancias que, según el autor, históricamente han asolado a la ciudad de Concepción. En sus párrafos, la naturaleza y la acción indolente de los "araucanos" no han dejado de socavar los pilares del proyecto civilizatorio de la ciudad. Pese a ello, la ciudad ha sabido levantar cabeza como él mismo señala, pudiendo doblar la mano al destino con el esfuerzo y el trabajo de una población cargada de espíritu de sacrificio y valor.

No dista mucho esta opinión de la que tuviese en 1948 el mismo Fernand Braudel en su comentario crítico Chili, cette folie géographique (Braudel, 1948), refiriéndose a la obra de Benjamín Subercaseaux "Chile o una loca geografía". Braudel no ahorra en expresiones fatídicas como "Chile, el país más trágico de América Latina" o "que cada sufrimiento obliga al hombre a reaccionar y readaptarse". Sin embargo lo hace en un sentido profundamente geohistórico: no es posible separar la condición geográfica de las circunstancias históricas de un pueblo.

Abundantes antecedentes señalan que desde los tiempos de la conquista española, el proceso de fundación de ciudades emplazadas en la zona costera del Pacífico sur fue de cierta manera "boicoteado" por la naturaleza, impidiendo la estabilidad necesaria para impulsar el proceso civilizatorio sobre los territorios de la Corona española en Latinoamérica, siendo estos frecuentemente abatidos por desastres naturales. En el caso particular de Chile, estos eventos de la naturaleza han traído trabas al crecimiento económico y social de sus ciudades. A lo largo de todo el país algunos centros urbanos evidencian tanto en su arquitectura como en sus habitantes, los rezagos de los movimientos de la tierra y de la inclemencia del mar, lo que los ha llevado a construir una forma de vivir el espacio inseguro, mecanismos de adaptación a las catástrofes o, en palabras de Alain Musset (entre otros autores), a desarrollar una "cultura del riesgo". Pero ¿qué significa o en qué se traduce esta noción de cultura del riesgo? ¿Existe tal cultura efectiva en el acto de construir ciudad?

Tal como se ha señalado y se desprende de lo expuesto por Lara, desde sus orígenes la ciudad de Concepción ha sido abatida por terremotos y tsunamis de distintas intensidades. Fundada en un principio en la zona de Penco en el centro sur de Chile, lugar escogido por Pedro de Valdivia y donde permaneció por más de 200 años, la ciudad fue sacudida por grandes terremotos en los años 1570, 1657 y 1730 , sin disuadir a las autoridades de reconsiderar la localización de la población. Sin embargo la situación cambia ante la intensidad del terremoto de 1751, en donde según los relatos, nada quedó en pie (Figura $N^{\circ} 1$ ) (Mazzei De Grazia y Pacheco, 1985).

La acumulación del impacto de eventos de este tipo sobre la infraestructura de la ciudad y el nerviosismo de la población, influyeron en que las autoridades decidieran finalmente trasladar la ciudad de Concepción desde Penco hacia el sector del Valle de la Mocha $^{4}$ (luego de una compleja y conflictiva votación), alejando de esta manera al futuro polo de desarrollo de las áreas más expuestas a maremotos (Figura $N^{\circ} 2$ ). Esta reacción frente a las amenazas de la naturaleza, puede interpretarse como una forma de aceptar las

\footnotetext{
4 El Valle de La Mocha, sitio donde se emplaza actualmente la ciudad de Concepción, está situado sobre la ribera norte del río Biobío, al sur de su original emplazamiento en el sitio de Penco, lejos de la costa Pacífico (ver Figura $N^{\circ} 1$ ).
} 
Figura $\mathrm{N}^{\circ} 1$

Sitios considerados para el traslado de Concepción.

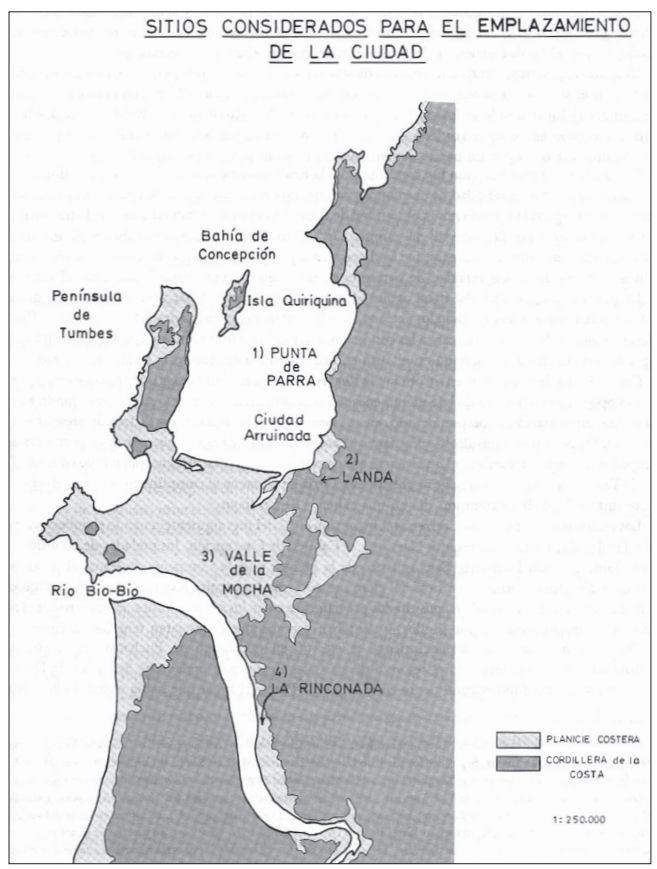

Fuente: Mazzei De Grazia y Pacheco (1985).

condiciones adversas del territorio, asumir el trauma como parte de la cotidianeidad social, y por consiguiente replicar la misma ciudad devastada en otro lugar nuevo, como una respuesta adaptativa al entorno. Este fenómeno de traslado urbano Musset lo define como

"una forma de resiliencia desarrollada por una comunidad frente a un acontecimiento desastroso, puesto que este tipo de respuesta le permite superar los estragos sufridos individual y colectivamente por todos sus miembros" (Musset, 2010:45).

En respuesta al terremoto del año 1835 en tanto, se realizaron los primeros estudios geológicos sobre la composición del suelo, subsuelo y la evolución de los terrenos sobre los cuales se emplazaba la ciudad de Concepción. Estos concordaban en declarar que los suelos cercanos a la ribera del río Biobío eran muy areniscos y por lo tanto, el menos apropiado para la edificación de ciudades. Del mismo modo se recomendó no habitar
Figura $\mathrm{N}^{\circ} 2$

Ubicación de Concepción en Penco (arriba) y en el Valle de La Mocha (abajo)

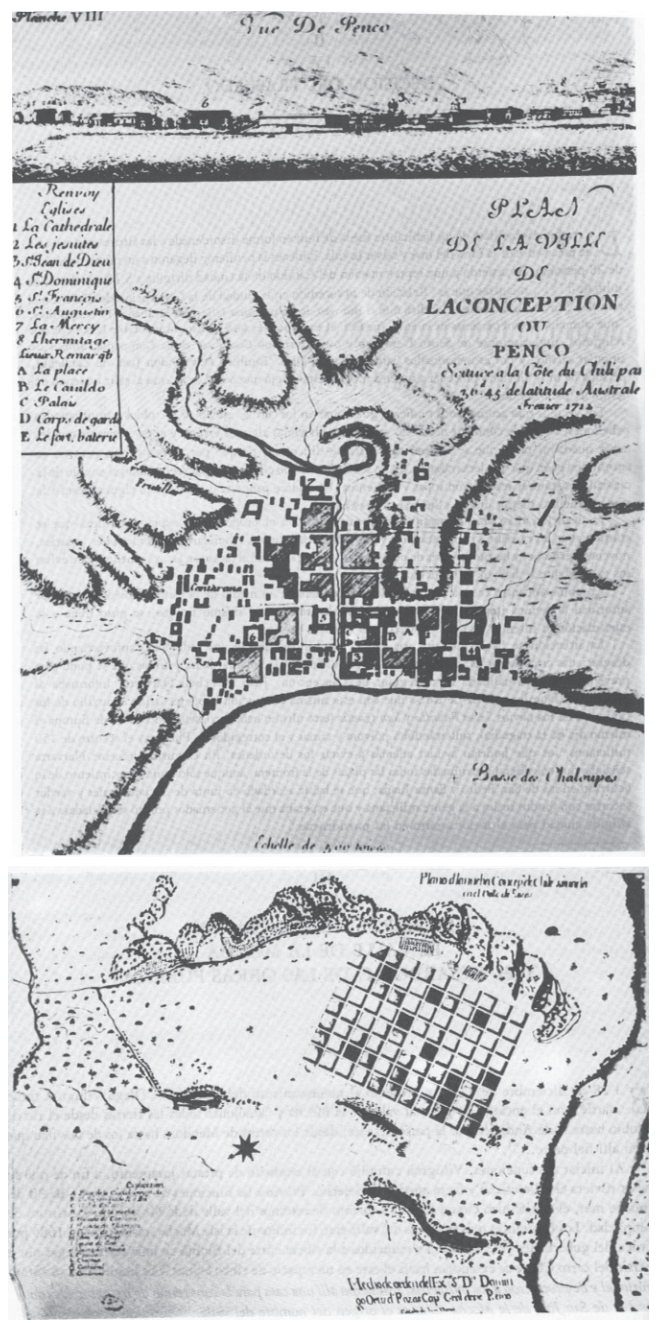

Fuente: Mazzei De Grazia y Pacheco (1985).

los terrenos bajos cercanos a la orilla del mar, para evitar el riesgo de ser impactados por un maremoto. A pesar del conocimiento físico del territorio y de la experiencia de quienes colonizaron la ciudad, las autoridades optaron reconstruir las ruinas en el mismo lugar tras cada remezón de la tierra en vez de tomar decisiones más drásticas para la seguridad de la población.

En los años posteriores, la ciudad de Concepción siguió creciendo en virtud de un 
comercio que por la vía marítima era muy promisorio y que llegó a conformar una dinámica actividad en la zona centro sur de Chile apoyado en el comercio y la industria (Mazzei De Grazia, 1990).

Con todo, ¿de qué modo quedan en la memoria de la ciudad los sucesos antes señalados? ¿Llegan a formar parte de las maneras de concebirse como condición propia de su pasado, su presente y más aun su futuro en tanto ciudad? ¿Qué significa hablar de reconstrucción en una ciudad que se reconstruye permanentemente? ¿A qué geografía se enfrenta la ciudad que vive en esta condición permanente de estar en reconstrucción? El presente trabajo busca dar cuenta de una exploración en el registro histórico de la ciudad frente a dos importantes sucesos que la marcan frente a esta condición de desastre y reconstrucción postdesastre. Para ello se indaga en los terremotos de 1939 y de 1960. Se trabaja así con fuentes tales como registros de prensa e informes ministeriales, de manera de explorar el relato y las narrativas que acompañan estos procesos.

Desde allí se busca reflexionar sobre la naturaleza de este proceso recurrente, considerando además para ello los elementos que subyacen silenciosamente en la memoria de la ciudad a causa de los desastres sufridos desde el siglo XVI. Asimismo, se estructura el análisis en función de la siguiente hipótesis: el Gran Concepción es una ciudad que en su estado de latencia permanente frente a procesos de reconstrucción, invisibiliza esta misma condición y por ello cae en el olvido. El ejercicio permanente de la ciudad en el plano de sus decisiones, es el olvido y por ello, los procesos de reconstrucción repiten errores, atributos y características pese al paso del tiempo, sin incurrir en conductas de preparación para el largo plazo.

\section{Concepción, la trágica capital del sur. Los sueños interrumpidos}

El crecimiento económico impulsado por una incipiente industrialización en la economía nacional, acompañado por la implementación de los servicios públicos e instituciones en las regiones del país, sirvió de motor para el crecimiento de las ciudades. La fundación y urbanización de comunas como Talcahuano, Penco (zona repoblada), Hualqui y Chiguayante, además de la creación de organismos penquistas como el Club Concepción, el Banco de Concepción (actual Corpbanca), la Sociedad Agrícola del Sur, el Diario el Sur, la Universidad de Concepción, la Confederación Nacional de Colonos, jugaron roles claves en el forjamiento urbano del Gran Concepción a principios del siglo XX.

Pero durante la madrugada del 20 de enero de 1939 Concepción fue sacudida bruscamente por un nuevo terremoto cuyo epicentro fue en la ciudad de Chillán, dejando un saldo de casi 30.000 muertos en la zona (Pacheco, 1997). La ciudad penquista quedó otra vez en las ruinas, devastada, edificios y viviendas destruidas, miles de muertos, heridos y cientos de niños huérfanos (Cuadro $N^{\circ} 1$ ). Los habitantes estaban sumidos en el caos frente a la carencia de víveres, agua potable, luz y servicios médicos; la epidemia de enfermedades era inminente y muchas familias pasaban las noches en las calles y plazas, la desesperación inundaba a la ciudad (Figura $\left.N^{\circ} 3\right)^{5}$.

El terremoto dejó inutilizables las vías férreas en varios tramos del sur del país, motivo que sumado al mal estado de los caminos posicionó al puerto de Talcahuano como el principal punto de conexión de la zona centro sur con el resto del territorio nacional. La evacuación de heridos, enfermos, niños, mujeres y ancianos se realizó por vía marítima hasta Valparaíso, siendo el transporte de pasajeros completamente gratuito. Una vez restablecido el servicio de trenes, el uso portuario y el flujo de vapores se limitó al transporte de víveres y donaciones para el auxilio de los damnificados. Los servicios de aprovisionamiento y subsistencia funcionaron de manera normal en Concepción, en cambio en otras comunas se dificultó mucho más, especialmente en las cuales nunca se habían construido vías férreas o en que estas se encontraban en mal estado por efecto del

\footnotetext{
5 "Chillán destruido totalmente: solo hay 4 casas en pie; en Concepción grandes destrozos: hay varios miles de muertos", revista Ercilla, 1939, № 195, p. 6.
} 


\section{Cuadro $\mathrm{N}^{\circ} 1$}

Destrucción de viviendas en provincia de Concepción por efecto del terremoto del 1939 (considerando techo hundido y murallas en el suelo)

\begin{tabular}{|l|r|r|r|}
\hline Ciudad & No total de casas & No casas destruidas & \% casas destruidas \\
\hline Concepción & 7.526 & 533 & 7 \\
\hline Penco & 549 & 224 & 41 \\
\hline Tomé & 823 & 88 & 27 \\
\hline
\end{tabular}

Fuente: Informe del Ministerio de Fomento, 1939.

terremoto, además de la insuficiencia de camiones ${ }^{6}$.

Frente a la crítica situación del sur del país y las desgarradoras imágenes que la prensa nacional dio a conocer tanto a nivel local como en el extranjero, surgió una suerte de espíritu de unidad nacional, reflejado en el mensaje enviado por el Presidente Pedro Aguirre Cerda a todo el país, donde declara:

"Estoy conmovido de la cooperación unánime del pueblo unificado en un poderoso sentimiento de ayuda para las regiones destruidas. (...) El país ya ha movilizado su espíritu y solo espera la voz de partida para proceder a restaurar lo que aniquiló el destino. Con este fin me apresuro a enviar al Parlamento un proyecto de ley que consulta algunas medidas indispensables de emergencia que permitirán dar forma a estos propósitos. Estoy seguro que el Parlamento concurrirá sin dilaciones a cooperar en esta cruzada patriótica" ${ }^{7}$.

Esta declaración es reafirmada con anterioridad por los dirigentes de los partidos políticos quienes manifestaron al Ministro del Interior su apoyo y colaboración en la tarea de ayuda y reconstrucción del país ${ }^{8}$. El

6 Ministerio del Interior. Carta del Intendente del Biobío, 1 de febrero de 1939.

7 "El Gobierno toma urgentes medidas frente a la catástrofe". Diario El Sur, Concepción. Miércoles 1 de febrero de 1939, p. 1.

8 "Todos los partidos políticos expresan deseos de cooperar al Gobierno ante la tragedia". Diario El Mercurio, Santiago. Jueves 26 de enero de 1939, cuerpo segundo, p. 21. apoyo fue ofrecido por el Partido Conservador, Partido Liberal, Partido Radical, Asamblea Radical, Asamblea Radical Femenina, Falange Nacional, Juventud Conservadora, Partido Socialista, la Unión Socialista, Partido Demócrata, y Alianza Popular Libertadora, todos quienes presentaron planes de trabajo de emergencia.

Con menos de dos meses en el cargo, el Presidente Pedro Aguirre Cerda decide crear nuevas instituciones para hacer frente a la tarea de la reconstrucción en las zonas devastadas, entre ellas la Corporación de Reconstrucción y Auxilio dependiente del Ministerio de Hacienda (actual ONEMI), y la Corporación de Fomento de la Producción $(\mathrm{CORFO})^{9}$. Esta última generó gran debate en el Congreso pues significaba un cambio económico-político de gran envergadura para el país previo al modelo de industrialización por sustitución de importaciones (ISI), un impulso a la industrialización ligada al Estado, que controlaría nuevas sociedades anónimas otorgándoles capitales, créditos especiales y un marco legal de protección (CORFO, 1962). La necesidad de reconstruir el país fue la condicionante principal para la votación de los parlamentarios, pues un escenario distinto no habría justificado este plan de desarrollo para quieres solo confiaban en el mercado interno (Lagos, 2011). En otras palabras, la propuesta de reconstrucción de Aguirre Cerda estaba estrechamente ligada

\footnotetext{
9 La Ley 6.634 del 29 de abril de 1939 crea la Corporación de Reconstrucción y Auxilio (actual Oficina Nacional de Emergencia, ONEMI) y la Corporación de Fomento de la Producción (CORFO).
} 
Figura $\mathrm{N}^{\circ} 3$

Imágenes posteriores al terremoto de 1939 en Concepción. Edificios y caminos afectados en el centro de la ciudad y alrededores
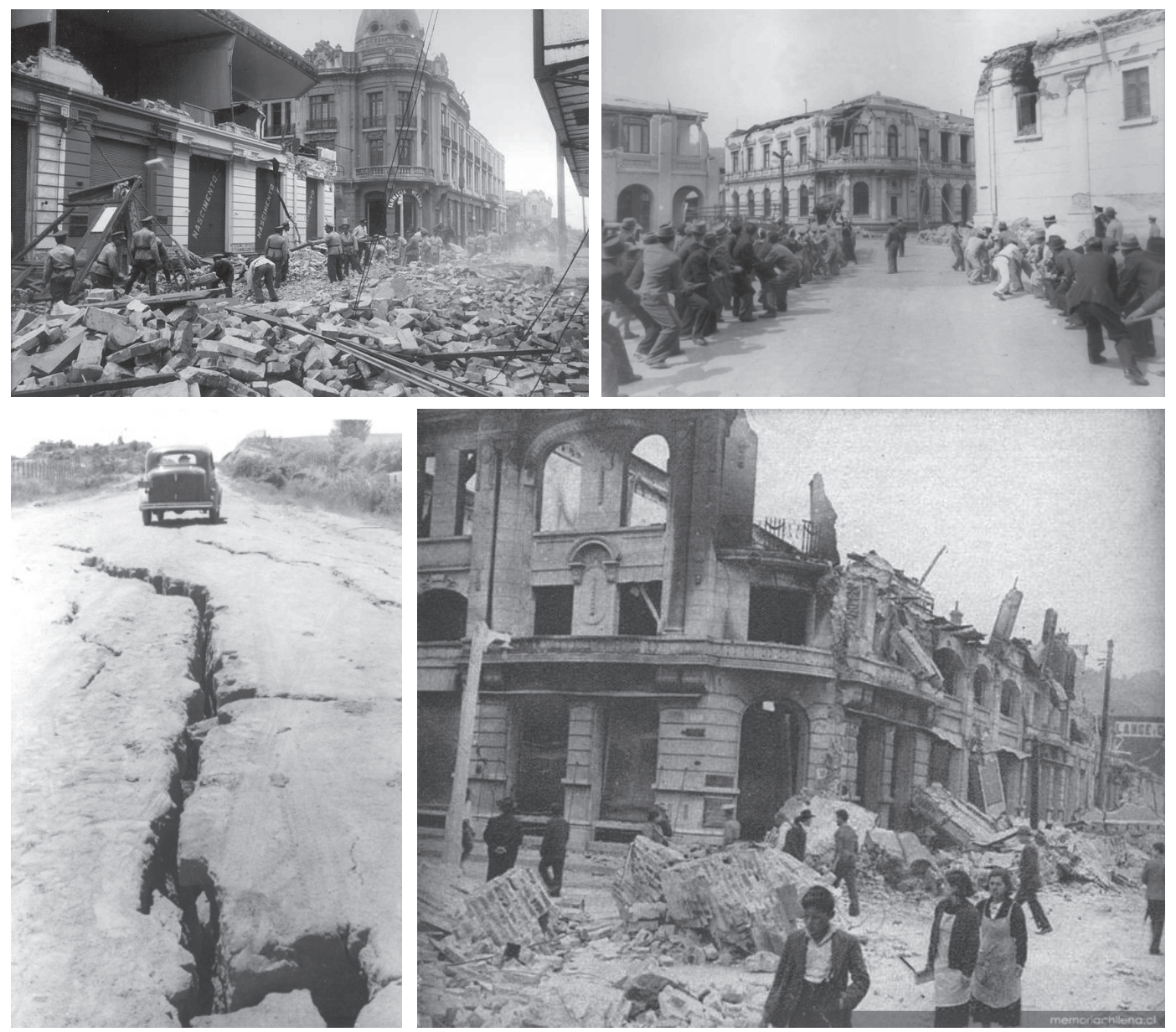

Fuente: Archivo fotográfico Sr. Alejandro Mihovilovic, Biblioteca Municipal de Concepción.

con un plan de desarrollo futuro para todo el país, transformando los efectos negativos del terremoto en una oportunidad para facilitar la aprobación de proyectos de su propia cartera administrativa.

Desde la capital del país se enviaron estrictas instrucciones a las zonas afectadas para sobrellevar la situación y distribuir la ayuda a los damnificados, donde el primer paso fue implementar nuevos cargos administrativos del Estado en cada comuna a cargo de militares quienes ejercían el rol de "Jefes de Plaza", y en algunos casos como el de la ciudad de Concepción, también cumplían las funciones de Intendente, por lo menos en los inicios de la operación. La tarea de la planificación y fiscalización del plan de auxilio fue encomendada al Ministerio del Interior, organismo que a través de un telégrafo ${ }^{10}$ enviado a todos los Intendentes de la zona centro sur que estaban involucrados en la tarea de la re-

${ }^{10}$ Circular N ${ }^{\circ} 818$ del 10 de marzo de 1939 sobre modalidades de conceder auxilios en dinero o especie a los damnificados. Evidenciado en carta del coronel Galvarino Zúñiga, Jefe de Plaza de Chillán, dirigida al Ministro del Interior con fecha 19/4/1939 solicitando estampillas gratuitas para que los damnificados pudieran acceder a tener cédula de identidad, documento indispensable para que pudieran acceder a la ayuda del gobierno. 
construcción, detallando los inflexibles conductos para la solicitud de dinero y su posterior distribución a los damnificados locales:

“El Ministerio del Interior centralizará toda la directiva en cuanto se refiere a la atención, aprovisionamiento y reconstrucción de la zona dañada por el terremoto y el Comando Militar de la zona afectada centralizará la acción en la zona que le corresponda. (...) Todos los giros necesarios para distribuir estos recursos serán visados por el Señor Ministro del Interior y de su inversión deberá rendirse cuenta documentada a la Contraloría General ${ }^{11 " .}$

Toda la ayuda económica recibida desde el exterior y de donaciones de los nacionales sería depositada en una cuenta especial de la Caja Nacional de Ahorros de Santiago, centralizando la responsabilidad en la Tesorería General de la República.

La ayuda internacional no demoró en llegar a los puertos de Valparaíso y San Antonio que habían sido definidos para el acopio de ayuda, esfuerzos sumados a un precario puente aéreo entre Santiago y la Región del Biobío para el traslado de los voluntarios de la Cruz Roja Chilena y la Americana. El mal estado de los caminos, la destrucción de las vías férreas y la escasez de vehículos y camiones, influyeron en el potenciamiento del Puerto de Talcahuano para el traslado de heridos y huérfanos hacia Valparaíso, así como para el acopio de víveres y abrigos enviados por la ayuda internacional. La única vía de comunicación entre el puerto y la capital de la provincia era el ferrocarril, pues no habían caminos en buen estado; sin embargo los daños en las vías férreas, sumado a los constantes derrumbes, dejaron muchas veces incomunicada por largos períodos a Concepción ${ }^{12}$, impidiendo el abastecimiento efectivo de la ayuda recibida.

\footnotetext{
11 Instrucciones Generales. Dirección General de Obras Públicas, Departamento de Caminos, Sección Control. 1939 Archivo Nacional, vol. No 9994. En cumplimiento a lo acordado al Consejo de Gabinete del día 30 de enero de 1939.

12 Carta del Comandante de crucero Blanco Encalada al Ministro de Fomento, 13 de marzo de 1939. Archivo Nacional, Vol. № 9995.
}

Entre los meses de marzo y mayo de 1939 numerosas naves atracaron en el puerto de Talcahuano. Entre otras Ilegaron el vapor Puyehue, el vapor Alondra, el buque Prudente Moraes (brasileño), el crucero Blanco Encalada, el vapor Marañon (peruano), el Jeanne D'Arc (francés), todos los cuales jugaron un papel fundamental para el transporte de toneladas de víveres, fardos de vestuario e incontables pasajeros. En este período, la distribución de la ayuda para los damnificados de la provincia de Concepción fue estrictamente controlada por el Comandante en Jefe del Apostadero Naval, cargo también militarizado por instrucciones del gobierno. Los problemas respecto a la incongruencia de las cargas declaradas en Santiago y la carga final declarada en el Apostadero Naval motivaron al jefe de este centro para enviar una carta al Ministro del Interior declarando la falsa información que se publica en la prensa, quienes aseguraban que el vapor Marañon trasladaría hasta Talcahuano una carga de auxilio cercana a las 5.000 toneladas, cuando el volumen efectivamente recibido en el apostadero naval alcanzó apenas 454 toneladas brutas. De este cargamento, el $60 \%$ se entregó a la ciudad de Concepción, en tanto que el resto en parte al Jefe de Plaza y a asilos y casas de acogida, recalcando que estos últimos asilados no son solo los damnificados por el terremoto, sino casi en su mayor parte "damnificados de la vida"13.

A pesar de los intentos del Gobierno por transparentar y distribuir equitativamente la ayuda a los miles de habitantes de la actual octava región, las desigualdades, la demora y el mal estado de los caminos que dejaron incomunicadas varias localidades del sur, dificultaron el plan de auxilio entrampado por procedimientos burocráticos. Las críticas de la población y de las autoridades locales fueron evidenciadas en distintos canales de prensa donde se manifestaba que la distribución de ayuda (víveres y abrigo) en las zonas afectadas no guardaba relación alguna con la verdadera necesidad de las distintas comunas, pues no se considera información del número de damnificados ni el número de

\footnotetext{
13 Carta del Comandante en Jefe del Apostadero Naval al Ministro del Interior, 13 de mayo de 1939. Archivo Nacional, Vol. № 9995.
} 
habitantes. Talcahuano por ejemplo recibió una cantidad de auxilio 6 veces mayor a la que recibió Tomé, siendo esta última ciudad prácticamente destruida por el terremoto ${ }^{14}$.

Fue tan lento y engorroso el procedimiento para recibir ayuda económica ${ }^{15}$ que al pasar los meses sin respuesta, los habitantes de Concepción comenzaron a organizarse por cuenta propia para exigir ayuda y atención a las autoridades en Santiago. Surgió de esta manera el Comité de Damnificados de Concepción ${ }^{16}$, quienes en paralelo a juntas de vecinos, sindicatos e incluso personas naturales, comenzaron a enviar cartas particulares directamente al Ministro del Interior ${ }^{17}$ solicitando ayuda, haciendo caso omiso a las instrucciones dadas desde un comienzo al Intendente, tras no recibir ayuda alguna por parte de sus autoridades locales ${ }^{18}$.

Recién dos meses después del terremoto que sacudió el sur de Chile, algunas autoridades solicitan al Ministro del Interior la visita de asistentes sociales a la zona afectada con el fin de organizar debidamente la distribución de ropa y víveres a la población ${ }^{19}$, hechos que denotan el desconocimiento y poca preparación de parte del aparato estatal para responder a catástrofes, existiendo ya registro histórico que evidencia a los terremotos como eventos recurrentes en territorio

${ }^{14}$ Carta del Jefe Militar de la zona de Tomé al Ministro del Interior, 10 de abril de 1939. Archivo Nacional, Vol. N ${ }^{\circ} 9995$.

15 Intendente de Santiago informa al Ministro del Interior que los fondos puestos a disposición por el Gobierno solo cubren las necesidades mínimas de la población damnificada por un plazo de 30 días, por lo que solicita una nueva remesa de víveres o dinero a la brevedad, pues la situación es urgente (se cuenta solo con los fondos y donaciones recolectadas en la Tesorería Provincial). Archivo Nacional, 9 de abril de 1939.

16 Telegrama del Comité de Damnificados de Concepción al Presidente de la República, Folio 38 Línea 16, 12 de febrero de 1939. Archivo Nacional, Vol. No 9995

17 Ministerio del Interior, Comunicaciones No875, 15 de marzo de 1939. Archivo Nacional, Vol. № 9995.

18 Intendente de Cautín manifestó que no estaba autorizado para distribuir socorro si no estaba visado por el M. del Interior, 15 de marzo de 1939. Archivo Nacional, Vol. No 9995.

19 Telegrama del Jefe de Zona de Tomé al Ministro del Interior, 20 de marzo de 1939. Archivo Nacional, Vol. No 9995. chileno y particularmente en la zona de Concepción (Musset, 2010; Mazzei de Grazia y Pacheco, 1985).

La medida de asignar asistentes sociales a distintos puntos de la zona afectada para confirmar las reales necesidades de ayuda en cada pueblo no fue efectiva (o quizás no se llevó a cabo de esta manera), pues en una carta enviada al Ministro del Interior se informa sobre la distribución de mercadería procedente del vapor Alondra donde se abstiene el reparto a las ciudades de Constitución y Coronel explicando que habría un "supuesto" bajo porcentaje de destrucción de estas zonas (alcanzando un 10\%). Según la autoridad, no se justificaba el reparto de ayuda en estas zonas ni a Collipulli, Traiguén ni Victoria, pues la destrucción en estos puntos sería "insignificante" 20 . La situación era tan insostenible que incluso algunos damnificados solicitaron ayuda de manera particular directamente al Ministro del Interior. Incluso Jefes de Plaza como el de Penco, solicita autorización directamente al Ministro del Interior para utilizar fondos de la Caja Nacional de Ahorro para dar préstamos de auxilio y pagar a jornaleros que retiren escombros de la ciudad, pues el Intendente demora la aprobación para utilización de recursos al seguir el instructivo enviado por el Ministerio del Interior ${ }^{21}$.

Antes incluso de debatir el proyecto de ley para reconstrucción en el Congreso, la Secretaría General de Gobierno habría enviado una carta con calidad de "urgente y confidencial" al Ministerio del Interior don Pedro Enrique Alfonso, encargándole la labor de recopilar información necesaria para reseñar sintéticamente la labor del Gobierno frente al terremoto del 24 de enero y el plan de trabajo planteado, a fin mostrar a todo el país, pero principalmente al extranjero, la la-

\footnotetext{
20 "Propone reparto de artículos de vestuario llegados por Vapor Alondra. Carta enviada por autoridades a cargo del acopio de mercadería en Valparaíso al Ministro del Interior. Dirección General №2508, 7 de mayo de 1939. Archivo Nacional, Vol. № 9995.

21 Telegrama con prioridad enviado por el Jefe de Plaza de Penco al Ministro del Interior. Telégrafo del Estado, 4 de abril de 1939. Archivo Nacional, Vol. No 9995.
} 
bor del Gobierno 22 . Esta iniciativa tan urgente denota la necesidad del Gobierno de mostrar una imagen política positiva y triunfante ante la tempestad. El informe del Intendente de Santiago al Ministro del Interior en respuesta a la solicitud de información para la prensa internacional, menciona que el auxilio fue "entusiasta y abnegado de innumerables cooperadores" y que "la rapidez con que se ha llegado a una relativa normalidad del trabajo de restauración, hacen mirar como muy lejana la nefasta fecha de la catástrofe"23.

Pese al breve período de tiempo transcurrido desde el terremoto y aun cuando no hay proyecto ni presupuesto para la reconstrucción, la opinión del Ministro es extremadamente triunfalista y alejada de lo que sucede en el sur del país. Por lo demás, esta declaración se contradice con la evidencia mostrada por la Municipalidad de Concepción, donde su máxima autoridad debió recurrir directamente al Presidente de la República para solicitar fondos para mantener los servicios de carácter indispensable para el funcionamiento de la ciudad, tales como alumbrado público, aseo, subsistencia, reconstrucción y reparación de edificios públicos ${ }^{24}$.

La aprobación del Proyecto de Ley de recursos extraordinarios para la reconstrucción, previamente aprobado por el Consejo de Ministros, fue enviado al Congreso por el Gobierno el 30 de enero de 1939 (según registra la prensa nacional); este encontró detractores en ambas cámaras y fue frenado durante meses por los parlamentarios de la oposición. El proyecto oficialista proponía la asignación de 2.000 millones de pesos para la atención de las necesidades de la población afectada y otros 500 millones para contrarrestar los efectos de la catástrofe en la economía ${ }^{25}$,

\footnotetext{
22 Secretaría General de Gobierno, 8 de marzo de 1939. Archivo Nacional, Vol. No 9995

23 Secretaría General de Gobierno, 8 de marzo de 1939. Archivo Nacional, Vol. No 9995

${ }^{24}$ Carta del Alcalde de la Ilustre Municipalidad de Concepción al Ministro de Hacienda, Comunicaciones 206/16, 17 de marzo de 1939. Archivo Nacional, Vol. No 9994.

25 "Recursos extraordinarios hasta por 2,500 millones de pesos requiere el Gobierno de la República". Diario El Mercurio, Santiago. Miércoles 1 de febrero de 1939, Cuerpo primero, p. 1.
}

además de otras estructuras administrativas para facultar a los Jefes de Plaza para ejercer como Intendentes y Gobernadores de las provincias afectadas. Por su parte el Partido Liberal también presentó un proyecto de ley para la reconstrucción ${ }^{26}$, el cual fue en pocos días modificado por diputados liberales y conservadores antes de presentarlo al Congreso, proponiendo reducir el presupuesto de recursos extraordinarios a 750 millones de pesos. Por su parte, la Acción Republicana ${ }^{27}$ tampoco apoyaba la magnitud de la cifra para la rehabilitación del sur, declarando que podría acarrear una posible desvalorización de la moneda, entre otros trastornos. Los parlamentarios de derecha de la Comisión de Hacienda de la Cámara de Diputados se oponían rotundamente al Plan de Fomento de la Producción Nacional, pues a pesar de las modificaciones, los puntos de discrepancia continuaban concentrándose en las cifras económicas, además de considerarlo "inoportuno y falto de estudio" ${ }^{\prime 2}$. Al día siguiente, la Cámara de Diputados rechazó el proyecto del Ejecutivo sobre recursos extraordinarios para la reconstrucción por 7 votos contra 6, pero sin embargo se aprobó otro proyecto para el auxilio de los damnificados y la reconstrucción por 1.000 millones de $\operatorname{pesos}^{29}$, el cual fue dado a conocer por el Ministro de Hacienda a través de una amplia declaración.

Días después se retiraron todos los proyectos de la tribuna y el Presidente firmó un nuevo proyecto de ley $^{30}$ que armonizaría las distintas propuestas de los parlamentarios de izquierda y derecha, aunque los socialistas declararon no conocer la propuesta. El último proyecto contemplaba asignar 2.000 millones

\footnotetext{
26 "Modificaciones al proyecto de la Junta Ejecutiva Liberal". Diario El Mercurio, Santiago. Miércoles 1 de febrero de 1939, Cuerpo segundo, p. 12.

27 "No se ve razón para financiar desde luego la cifra global". Diario El Mercurio, Santiago. Miércoles 8 de febrero de 1939, Cuerpo segundo, p. 17.

28 "No se llegó a fórmula de acuerdo en proyecto de recursos extraordinarios". Diario El Mercurio, Santiago. Martes 14 de febrero de 1939, Cuerpo segundo, p. 9.

29 "Volvió a reunirse la Comisión de Hacienda de la Cámara de Diputados". Diario El Mercurio, Santiago. Martes 15 de febrero de 1939, Cuerpo segundo, p. 1.

30 "El Presidente de la Republica firmó nuevo proyecto de auxilio". Diario El Mercurio, Santiago. Sábado 18 de febrero de 1939, Cuerpo segundo, p. 9.
} 
de pesos para auxilio, reconstrucción y fomento de la producción, y 500 millones para la habitación popular ${ }^{31}$. Luego de muchas sesiones, rechazos y modificaciones, finalmente en el mes de abril el Senado aprueba la Ley de Auxilio y Reconstrucción, a pesar del constante desacuerdo del Partido Liberal ${ }^{32}$.

Pese a la aprobación de la ley, el proceso de reconstrucción en Concepción fue extenuantemente largo, pues los efectos que acarreó el terremoto desde el punto de vista social, laboral, estructural, arquitectónico, económico y agrícola, fueron inconmensurables. En octubre de 1939 había 1.500 cesantes en Concepción ${ }^{33}$ y no se había dado solución a necesidades como un tanque de agua con capacidad para 24 horas, un hospital regional, escuelas y reconstrucción de edificios.

Respecto a la reconstrucción de las ciudades destruidas, el Ministerio de Fomento designó una comisión por decreto para generar un informe de los efectos del terremoto en obras públicas y edificios particulares de las ciudades afectadas por este, considerando factores geológicos y geofísicos del territorio. Es así como en base a estos informes, expertos declararon que alrededor de un $80 \%$ de las edificaciones de Concepción debían ser demolidas $^{34}$. El estudio recomendó tajantemente modificaciones de carácter general que impida la edificación de adobe en la forma acostumbrada (incluso en los campos); sugiere que los edificios de hormigón armado se calculen tomando en cuenta la aceleración máxima, amplitud y período los temblores, además de medidas de resguardo contra futuros terremotos ${ }^{35}$.

31 "Dos mil millones para auxilios, reconstrucción y fomento de la producción y quinientos para habitación popular". Diario El Mercurio, Santiago. Martes 21 de febrero de 1939, Cuerpo segundo, p. 7.

32 "El Senado aprobó ayer en general el Proyecto de Ley de Arbitrios". Diario El Mercurio, Santiago. Jueves 26 de marzo de 1939, Cuerpo segundo, p. 12.

33 "Hay mil quinientos cesantes en Concepción: hace falta un hospital clínico regional". Revista VEA $\mathrm{N}^{\circ} 27,18$ de octubre de 1939 , p. 36

34 "Concepción: el 80 por ciento de la edificación actual debe ser demolida". Diario El Mercurio, Santiago. Domingo 12 de febrero de 1939, Cuerpo segundo, p. 28.

35 Informe Ministerio de Obras Públicas, en Archivo Nacional.
En estas fechas ya se tenía conocimiento de las bases geológicas de la zona, determinando que las ciudades de Penco y Tomé se emplazan sobre un subsuelo formado por filitas y micacitas o sedimentos del Cretácico Superior y Terciario. En cambio la ciudad de Concepción estaría edificada sobre las arenas modernas del río Biobío, las que rellenan la depresión entre la península de Tumbes y el cordón granítico del cerro Caracol. Sin embargo el informe concluye que "de los efectos producidos por el terremoto se deduce que no hay relación bien visible entre la calidad del terreno y la destrucción ocasionada", atribuyéndole la destrucción a factores exclusivamente sísmicos. El informe también sugiere la delimitación de zonas de menor o mayor intensidad sísmica en el territorio nacional y determina que la existencia de edificios construidos con anterioridad a la vigencia de la actual Ordenanza General de Construcciones significaría un peligro evidente para la vida y los bienes de la población, debido a que no considerarían condiciones mínimas de antisismicidad. Finalmente, se discutió un proyecto de ley para la modificación de varios artículos de la Ley General de Construcciones y Urbanización vigente a la fecha ${ }^{36}$.

El Ministerio de Fomento finalmente redactó un Plan para la Reconstrucción de las ciudades devastadas proponiendo tres etapas; la construcción de barracas para dar techo a las familias damnificadas, construcción de poblaciones de emergencia, casas en serie y edificios para el funcionamiento de los servicios públicos, y culminado en una última etapa de construcción de ciudades definitivas con viviendas antisísmicas ${ }^{37}$.

El terremoto de 1939 dejó la ciudad de Concepción en tal estado de destrucción que las autoridades se vieron en la necesidad de pensar e impulsar cambios importantes en el modo de concebir la ciudad y la economía: la creación de la Corporación de Fomento de la Producción (CORFO), de la Corporación

\footnotetext{
36 Informe Ministerio de Obras Públicas, en Archivo Nacional.

37 "Tres aspectos contempla el plan de reconstrucción de ciudades devastadas". Diario El Mercurio, Santiago. Martes 14 de febrero de 1939, Cuerpo segundo, p. 12.
} 
de Reconstrucción y Auxilio (actual Oficina Nacional de Emergencia, ONEMI) y las modificaciones a la Ley de Urbanismo y Construcciones. Al mismo tiempo, puede verse que al comparar las narrativas de la prensa de la época, las discusiones parlamentarias y la acción de las autoridades, no parece haber mucha diferencia con lo recientemente vivido en la zona durante el año 2010.

\section{Concepción, la ciudad desgarrada una vez más}

El 21 de mayo de 1960, después de una noche de jolgorio antes del feriado, un potente terremoto remeció a la ciudad de Concepción. Una vez más la ciudad quedaba en el suelo (Figura $\mathrm{N}^{\circ} 4$ ). Las noticias sobre la catástrofe fueron confusas y escasas, en tanto en la zona central del país la gente comenzaba a disfrutar un día de fiesta, y en Santiago las calles se preparaban para el desfile militar. Luego de unas horas se dio la primera alerta de que un terremoto había ocurrido en Concepción, según relatan los cronistas de la revista Ercilla de aquella época:

"La pavorosa cordillera se desperezó y un movimiento sísmico ondulatorio estremeció la tierra y el litoral. Se quebró el sueño y estalló el alarido. (...) ¡Terremoto en Concepción! La ciudad seis veces golpeada volvía sufrir otro implacable latigazo. Bajo furiosa lluvia y en medio de la más pavorosa obscuridad, las murallas se derrumbaban, las cañerías de agua potable reventaron, lo mismo que los hornos de Huachipato, uno de los orgullos legítimos de Chile. Se había cortado el puente sobre el Bío-Bío y hasta los árboles habían sido arrancados de sus raíces" 38 .

El sismo alcanzó la magnitud de 7,5 grados en la escala de Richter, según el informe de la Estación Santa Lucía del Instituto Sismológico de la Universidad de Chile, aunque según dieron a conocer al diario $E I$ Mercurio, no fue posible conocer la intensidad ni tampoco el epicentro, pues las agujas

38 Reportaje "Ercilla y la tragedia". Revista Ercilla N ${ }^{\circ}$ 1305, p. 2. Miércoles 25 de mayo de 1960. de los instrumentos se habrían saltado de los marcadores ${ }^{39}$. Una cifra diferente indicó el Jefe de Zona de Carabineros de la sede de Concepción, donde el movimiento sísmico habría alcanzado los 8 grados. Los servicios de agua potable y gas se habrían restablecido al mediodía.

"En Concepción hay calles enteras prácticamente en el suelo, como Freire, Carrera y Maipú, entre muchas otras, cuyos edificios están por desmoronarse (...) En Talcahuano los daños son aún más cuantiosos, ya que su edificación es más antigua. La población está atemorizada. La gente no duerme en sus casas. Se van a las plazas o bien pasan en vela, hasta que aclara. El pánico se hace aún más penoso, ya que no hay ni agua, ni luz, ni teléfonos. En Concepción nos extrañó ver la forma lenta en que han actuado las autoridades (...) El intendente se olvidó de los niños y las mujeres estaban en las veredas, mientras en lo alto pedazos de murallones amenazaban con derrumbarse de un momento a otro. Los soldados estaban en el regimiento en vez de haber patrullado por las calles o trabajado en la botadura de escombros o de paredes peligrosas.

En cambio en Talcahuano, la marinería actuó de forma eficaz. El Apostadero Naval de ese puerto formó tres brigadas: una de orden y seguridad; otra de demolición; y una tercera de evacuación de los damnificados" 40 .

El Intendente de la provincia, Immanuel Holger, habría reunido rápidamente a las autoridades locales para disponer medidas de emergencia y comenzado a operar según lo estipulado en la Ley de Seguridad del Estado. A pesar de la dimensión de la tragedia, el Ministro del Interior a su regreso a Santiago tras una gira por la zona del sismo, declaró "La primera impresión al llegar a esa ciudad

\footnotetext{
39 "Terremoto en la zona sur del país causó graves daños materiales y pérdidas de vidas". Diario El Mercurio, Santiago. Domingo 22 de mayo de 1960, cuerpo segundo, Crónica, Cuerpo Segundo. p. ilegible.

40 Reportaje "Pequeños detalles de la gran tragedia", revista VEA No 1100, p. 20 . Jueves 26 de mayo de 1960.
} 
es de cierta normalidad y tranquilidad" (diario El Mercurio, 1960) ${ }^{41}$. La prensa por su parte manifiesta la impresión de una atónita población ya acostumbrada al aroma de la catástrofe:

"Lo que más impresiona en Concepción es la tranquilidad de la gente. Una calma excesiva que tiene más de shock que de serenidad. Por las calles, los grupos transitan lentamente, se detienen a mirar los daños, comentan en voz baja, sin demostrar emoción, con los ojos secos. (...) Es un pueblo que se ha entregado frente a una fuerza natural irresistible, contra la que no puede hacer nada. No hay explosiones ruidosas de dolor ni de ira ni de protesta" $^{\prime 4}$.

Pero también resaltan la dureza con la que han tenido que vivir los penquistas, soportando que los terremotos les destruyan sus casas una y otra vez, y en donde algunos han debido reconstruirlas tres veces en el plazo de 21 años:

“Es demasiado. En los espíritus más fuertes, los que primero han reaccionado, se nota un sentimiento de rebeldía. ¿Hasta cuándo? Se ve venir la idea de un éxodo en gran escala de habitantes que, después de aferrarse tenazmente a su patria chica, han empezado a pensar que no pueden seguir viviendo en ella. Este es, quizás el mayor peligro de la situación actual" 43 .

Una nota de la misma revista describe a Concepción encabezando la lista como una ciudad "record de Terremotos", según el análisis de un mapa de distribución de terremotos ocurridos en Chile, indicando las principales ciudades cercanas a sus epicentros de norte a sur del país, describiéndolo como

\footnotetext{
41 "Ministro del Interior realizó rápida gira por zona del sismo". Diario El Mercurio, Santiago. Domingo 22 de mayo de 1960, cuerpo segundo, Crónica, Cuerpo Segundo. p. 35.

42 "Con serenidad Impresionante los vecinos de Concepción afrontan los acontecimientos". Diario El Mercurio, Santiago. Lunes 23/05/1960, cuerpo segundo, Crónica, Cuerpo Segundo. p. ilegible.

43 libid.
}

"400 años de pánico"44. Las reiteradas y numerosas ocasiones en que Concepción ha sido abatida por siniestros sismos comenzó a Ilamar la atención de los chilenos en general y de los especialistas en particular, quienes a pesar de haber realizado numerosas investigaciones en todo el país por encargo de la CORFO en 1939, no habían logrado llegar a consenso respecto a la explicación de si el origen de los temblores recaía en las fosas submarinas o en las depresiones de la cordillera de los Andes. Sin embargo, la réplica del día 22 de mayo a las 15:11 hrs. en Concepción, cuyo epicentro estuvo situado en la ciudad de Valdivia, registró el mayor terremoto del que se tenga hasta ahora registro en la historia de la humanidad ${ }^{45}$. Este incluyó además del terremoto un maremoto que dejó miles de víctimas y una erupción volcánica ${ }^{46}$. El impacto de este último evento catastrófico fue mundial, pues además de las chocantes noticias que transmitían los medios de comunicación, se conocían efectos sobre las costas de Japón, Hawai, EE.UU., Filipinas, Australia y Nueva Zelanda ${ }^{47}$. En cuanto a Concepción, las réplicas fueron incontables; temblores con frecuencia de hasta cinco minutos y con intensidades bastante fuertes que dejaron nuevos saldos de muertos y heridos ${ }^{48}$.

No faltaron sin embargo las falsas declaraciones. El Ministerio del Interior declaró que dos diarios de circulación nacional habrían mentido sobre las consecuencias del terremoto. El diario "Clarín" en su portada del domingo 22 de mayo publicó que habría 300 muertos y 2.000 heridos por el terremoto en Concepción, y que habían desaparecido pueblos enteros incluyendo personas que

\footnotetext{
44 Reportaje "El trágico paralelo 37 sur". Revista Ercilla № 1305, p. 10. Miércoles 25 de mayo de 1960.

45 Reportaje "Concepción: Todos nos postergaron". Revista Ercilla No 1307, p. 9. Miércoles 8 de junio de 1960.

46 "Actividad volcánica coincide con movimientos sísmicos". Diario El Mercurio, Santiago. Martes 25 de mayo de 1960, portada Cuerpo primero, p.1.

47 "Terremotos ocurridos en Chile causan catástrofe en Japón, Hawai y Okinawa". Diario El Mercurio, Santiago. Martes 25 de mayo de 1960, portada Cuerpo primero, p.1.

48 "Repetidos temblores de gran violencia aumentaron la Tragedia en Concepción". Diario El Mercurio, Santiago. Lunes 23 de mayo de 1960, cuerpo segundo, Crónica, Cuerpo segundo. p. ilegible.
} 
Figura $N^{\circ} 4$

Imágenes posteriores al terremoto de 1960 en Concepción. Edificios dañados, misa a cielo abierto y puente sobre el río Biobío destruido
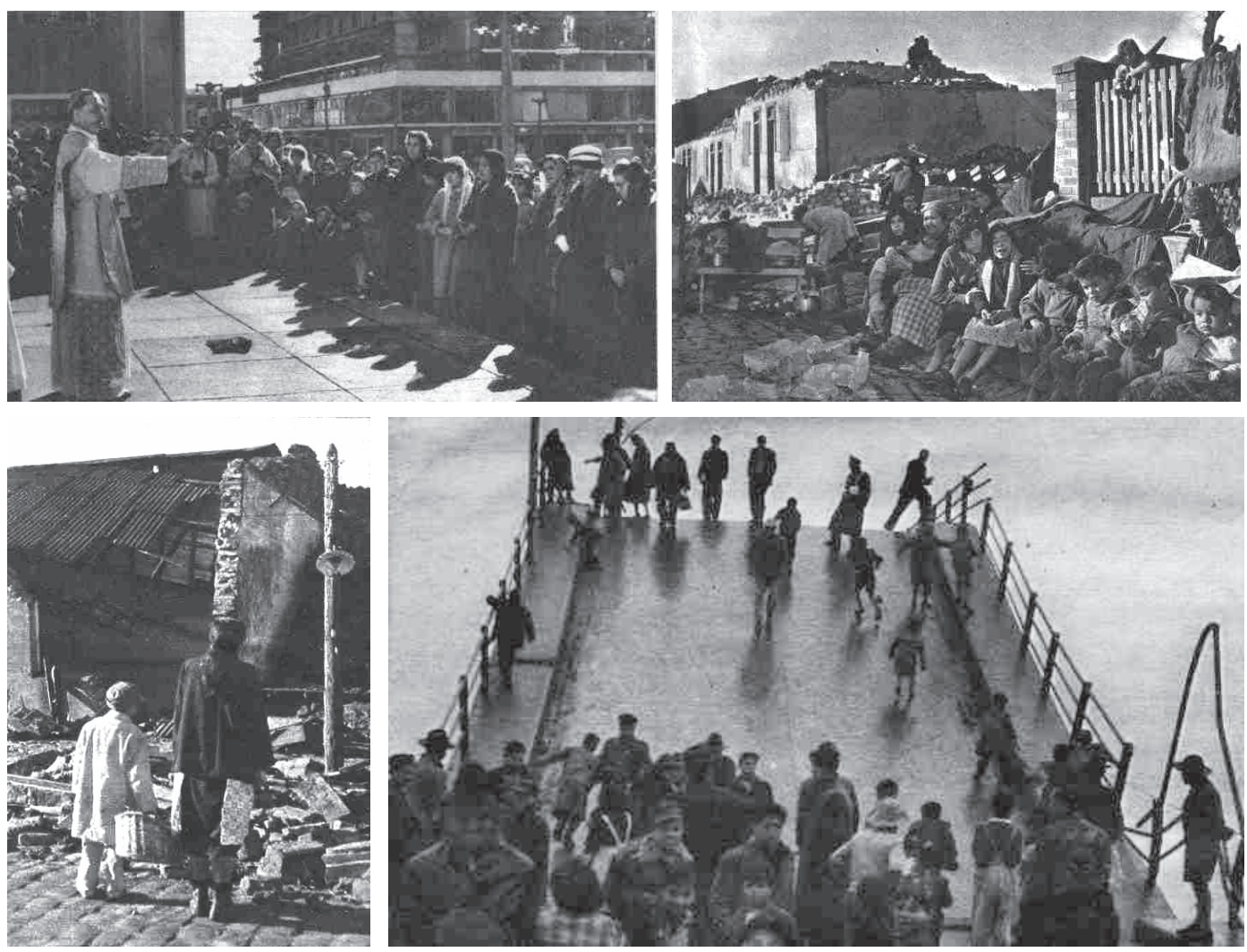

Fuente: Archivo fotográfico Sr. Alejandro Mihovilovic, Biblioteca Municipal de Concepción; Pacheco, 1997.

estarían enterradas vivas. El diario "El Siglo" por su parte, publicó que el saldo era de más de 200 muertos, agregando que pueblos casi enteros estaban en el suelo. El Gobierno recalcó que la información fidedigna sería proporcionada por la Oficina de Informaciones de la Presidencia ${ }^{49}$. No se puede obviar aquí sin embargo, la notable disputa ideológica y política que estaba en curso entre derecha e izquierda, que quedó fuertemente reflejada en las acciones posterremoto.

Se estimó finalmente un total entre 18 mil y 20 mil viviendas destruidas, además de

49 "Son falsas las informaciones de dos diarios". Diario El Mercurio, Santiago. Lunes 23 de mayo de 1960, Cuerpo segundo, Crónica, p. 16. unas 60 mil personas sin hogar ${ }^{50}$. Un $30 \%$ de las viviendas en Concepción habrían resultado destruidas y la planta de Huachipato alcanzó una destrucción parcial. El saldo de pérdidas en infraestructura de los hitos más importantes de la ciudad se resumen por ejemplo en 2 mil millones de pesos para la Universidad de Concepción, aunque el costo de la reposición sería el doble de lo señalado; en el sector industrial en tanto, unos 600 millones de pesos serían necesarios para la planta Siderúrgica de Huachipato, cuyo horno no alcanzó a estallar ${ }^{51}$. Un gran eslabón de la cadena productiva nacional

\footnotetext{
50 Reportaje "Olla común en Concepción". Revista Vea $\mathrm{N}^{\circ} 1102$, p. 24-25. Jueves 9 de junio de 1960.

51 "No existe peligro de paralización de las industrias básicas de Concepción". Diario El Mercurio, San-
} 
sin embargo habría caído, generando el colapso de la economía nacional, proponiendo desde algunos sectores la necesidad de una "descentralización de las industrias"52. En base a este planteamiento es que el diario $E l$ Mercurio publicó el muy criticado artículo "Peligrosa concentración industrial" el martes 24 de marzo, objetado por una amplia gama de opiniones que lo refutaban ${ }^{53}$.

Las medidas para mantener la comunicación con las provincias dañadas del sur fueron rápidas: el servicio de ferrocarriles fue restablecido prontamente por lo menos hasta Temuco un par de días después del segundo terremoto, el puente sobre el río Biobío también fue reparado al correr la primera semana ${ }^{54}$.

La ayuda internacional no se hizo esperar ${ }^{55}$; Gran Bretaña, Alemania, Unión Soviética, Italia, Argentina, Perú, Cuba, India y Estados Unidos hicieron aportes fundamentales en horas en que el Gobierno chileno aún no tomaba medidas. El Presidente Eisenhower de los EE.UU. motivó al pueblo norteamericano a solidarizar con la desgracia chilena ${ }^{56}$, enviando cerca de 24 Globe Masters de la fuerza aérea, transformándose en el pilar del puente aéreo solidario ${ }^{57}$. Posteriormente se

tiago. Lunes 23 de mayo de 1960, cuerpo segundo, Crónica, Cuerpo segundo, p. 9.

52 Reportaje "72 horas después: la ciudad que no se resigna". Revista Ercilla No 1306, p. 9. Miércoles 1 de junio de 1960.

${ }^{53}$ Reportaje "Olla común en Concepción". Revista Vea № 1102, p. 24-25. Jueves 9 de junio de 1960. Lo señalado por El Mercurio venía a reflotar la vieja disputa entre Santiago y Concepción referida a las críticas que esta última realizó a la alta concentración de poder a nivel nacional existente en Santiago. De alguna forma, el impulso industrial en Concepción respondía a un intento descentralizador, razón por la que se rechazó lo sostenido por el artículo de El Mercurio citado por revista Vea.

${ }^{54}$ Reportaje "El sur renace de las ruinas". Revista Vea $\mathrm{N}^{\circ} 1101$, p. 16. Jueves 2 de junio de 1960

55 "Preocupación Mundial ante la magnitud de la catástrofe ocurrida en el sur". Diario El Mercurio, Santiago. Lunes 23 de mayo de 1960, Cuerpo segundo, Exclusivos del exterior, p. 26.

56 "Estados Unidos considera un programa gigante de auxilio económico a Chile". Diario El Mercurio, Santiago. Jueves 26 de mayo de 1960, Cuerpo segundo, p. 15.

57 "Se exterioriza solidaridad mundial ante más extenso desastre natural del siglo". Diario El Mercurio, aumentó a 60 el número de aviones que transitaban ininterrumpidamente entre EE.UU. y Chile $^{58}$. La carga incluía 4 hospitales desmontables, helicópteros, ambulancias y toneladas de ropa, medicina y víveres.

Los países latinoamericanos a través del Plan Betancourt ${ }^{59}$, también fueron en ayuda de Chile. La iniciativa adhería a varios países de la región encabezados Venezuela y su Presidente Rómulo Betancourt (Lagos, 2011). La Cruz Roja internacional nuevamente coordinó la ayuda pare los damnificados y se hizo presente en el sur del país gracias a la ayuda de aviones canadienses ${ }^{60}$. También la OEA ofreció al Gobierno chileno ayuda técnica y colaboración para la reconstrucción ${ }^{61}$.

Las primeras medidas adoptadas por el Gobierno del Presidente Jorge Alessandri R., fueron:

- Estabilización de precios ${ }^{62}$.

- Decreto que autoriza la requisición de artículos esenciales ${ }^{63}$. Los intendentes y gobernadores seguirían instrucciones del Ministerio del Interior para requisar, racionar y abastecer a la población.

- 2.726 viviendas terminadas y 9.930 por construir en los próximos 90 días. Se da inicio a la construcción de viviendas provisionales ${ }^{64}$.

Santiago. Viernes 27 de mayo de 1960, Cuerpo primero, p. 1.

58 "Puente aéreo gigante entre EE.UU. y Chile fue elevado a 60 aviones". Diario El Mercurio, Santiago. Lunes 30 de mayo de 1960Seción Exclusivos del exterior, p. 24.

59 "Venezuela pide una acción interamericana inmediata y coordinada a favor de Chile". Diario El Mercurio, Santiago. Sábado 28 de mayo de 1960, Cuerpo segundo, p. 27.

60 "Dos aviones canadienses transportan auxilio de la Cruz Roja para Chile". Diario El Mercurio, Santiago. Martes 31 de mayo de 1960, Cuerpo primero, p. 1.

61 "Cruz Roja internacional anuncia ayuda de ocho naciones para los damnificados". Diario El Mercurio, Santiago. Miércoles 25 de mayo de 1960, Cuerpo segundo.

62 "Estabilización de precios en todo el país fue decretada por el Ejecutivo". Diario El Mercurio, Santiago. Jueves 26 de mayo de 1960, Cuerpo primero, p. 1.

63 "Fue dictado decreto que autoriza la requisición de artículos escenciales". Diario El Mercurio, Santiago. Viernes 27 de mayo de 1960, Cuerpo segundo, p. 15

64 "El Gobierno afronta el problema habitacional en numerosas ciudades". Diario El Mercurio, Santiago. Sábado 28 de mayo de 1960, Cónicas, p. 14. 
- Se encomienda a CORFO evaluar daños ${ }^{65}$.

Días después de la catástrofe, los parlamentarios declararon unidad con el fin de contribuir con la acción del Gobierno, deponiendo diferencias partidistas a favor de agilizar las legislaciones necesarias ante la tragedia ${ }^{66}$. Sin embargo otra vez el auxilio fue retardado a causa de la mala organización de las autoridades; confusión entre las atribuciones de la Intendencia del Biobío, las alcaldías y las Fuerzas Armadas provenientes de Santiago. Esta situación trunca el flujo de la ayuda a los 15 mil habitantes afectados que se encontraban sin techo ${ }^{67}$. Al parecer era frecuente la falta de comunicación entre la Compañía de Electricidad, la Compañía de Teléfonos y las Fuerzas Armadas, pues existen varios reclamos registrados sobre la contradicción de sus actos. Mientras por una parte las dos primeras reparaban el cableado eléctrico y las líneas telefónicas, por otra las Fuerzas Armadas demolían edificios en mal estado sin piedad, echando abajo postes de luz y dejando barrios enteros a oscuras. Estos hechos llevaron a la Compañía de Teléfonos a declarar que había más teléfonos en mal estado debido a las demoliciones que por efectos del terremoto. A esto se suma el actuar de la Municipalidad de Concepción, que obviando las órdenes de demolición de las autoridades regionales, autorizó reparaciones y construcciones sin regulación. Aun así, se pueden rescatar resultados positivos como la aplicación de la nueva ordenanza de la Ley General de Construcciones implementada con posterioridad al terremoto de 1939. Según la revista Ercilla, los edificios antisísmicos construidos siguiendo las nuevas regulaciones, resistieron perfectamente los embates del terremoto, al contrario de los edificios anteriores a la ordenanza y aquellos que fueron reparados en su misma estructura.

\footnotetext{
65 "Coordinación de esfuerzos para reconstrucción económica del sur". Diario El Mercurio, Santiago. Sábado 28 de mayo de 1960, Cónicas, P. 23.

66 "Unanimidad en deponer diferencias partidistas ante la tragedia del sur". Diario El Mercurio, Santiago. Miércoles 25 de mayo de 1960, Cuerpo segundo, P. 27.

${ }^{67}$ Reportaje "72 horas después: la ciudad que no se resigna". Revista Ercilla № 1306, p. 9. Miércoles 1 de junio de 1960.
}

Buscando apurar el auxilio a las víctimas de este nuevo sismo, el senador por la provincia del Ñuble, Concepción y Arauco, don Humberto Martones Quezada, presentó un proyecto de ley al Senado, planteando restablecer, por nombrar algunas acciones, las medidas de la Ley de Reconstrucción y Auxilio aplicada en 1939 considerando una actualización, además de designar a la Corporación de la Vivienda (CORVI) como la principal institución a cargo de la reconstrucción, aumentando sus recursos en 10 millones de escudos y disponiendo de ellos, con cargo a las utilidades generadas por la exportación de cobre. Esta última medida permitiría conceder préstamos a las personas afectadas para la autoconstrucción de sus viviendas destruidas. Otra medida fue autorizar al Banco del Estado para otorgar créditos controlados a pequeños empresarios industriales, pescadores y artesanos. Mientras tanto, otros políticos fueron de la idea de que no existían en Chile los recursos económicos suficientes para financiar un plan de reconstrucción y auxilio necesario para superar los efectos catastróficos del terremoto y que la única solución por lo tanto recaería entonces en formular un "Plan Marshall" para Chile con donaciones internacionales ${ }^{68}$.

Algunas de las principales consideraciones que incluye el Gobierno en el proyecto de ley que envía al congreso, fue fortalecer las competencias de la CORVI y la CORFO como los principales ejes para la reconstrucción del país. Serían modificados los estatutos de la CORVI con el fin de que este organismo pudiera centralizar el plan de construcción de 150 mil viviendas destruidas por el terremoto y maremoto. También se reestructuraría la CORFO para que se encargue de centralizar la planificación económica de las once provincias que fueron afectadas. El proceso de reconstrucción estuvo atravesado por comentarios sobre eventuales prolongaciones de los períodos parlamentarios para evitar entrar en campañas políticas cuando aun había mucho trabajo por hacer ${ }^{69}$.

\footnotetext{
68 Reportaje "72 horas después: la ciudad que no se resigna". Revista Ercilla No 1306, p. 9. Miércoles 1 de junio de 1960.

${ }^{69}$ Reportaje "Ayuda total a la zona sur estudia el Gobierno". Revista Vea No 1101, p. 20 y 21. Jueves 2 de junio de 1960.
} 
Dos semanas después del dramático episodio, el director (s) de Vialidad en Santiago le solicitaba con suma urgencia al Ministro de Obras Públicas los fondos necesarios para enviar a las provincias afectadas por el sismo los instrumentos elementales para realizar obras de emergencia ${ }^{70}$. Esta carta fue redirigida dos meses después por el subsecretario general de Obras Públicas al Ministerio de Hacienda, remitiéndoles el problema para su solución.

El puerto de Talcahuano nuevamente cumplió un rol fundamental, y desde ahí el personal de Defensa de Costa normalizaba la situación en Tomé y en Concepción ${ }^{71}$. Nuevamente cientos de niños quedaron sin techo y algunos también huérfanos. Tras el colapso de las edificaciones de Lota, la Unión de Profesores del Puerto decidió enviar 82 niños hijos de mineros a Valparaíso en microbuses. En tanto los niños huérfanos de la provincia en su mayoría fueron enviados a la obra "Mi Casa" fundada recientemente en Temuco ${ }^{72}$.

Por otra parte, un error tipográfico del diario El Mercurio (domingo 29, revista semanal) indicaba que los daños sufridos en Concepción eran de 30 casas destruidas y 30 casas semidestruidas, lo que generó que algunos senadores, la Cámara de la Construcción, y "Reporter Esso" que grababa un documental sobre el terremoto, no consideraran a Concepción como una ciudad afectada ni mucho menos, dándole prioridad a la zona austral. Estos hechos influyeron en las bajas estadísticas de producción y comercio en la ciudad, además de provocar la ira de los penquistas, quienes nuevamente debieron tomar la iniciativa para solicitar recursos y auxilio al Gobierno.

${ }^{70}$ Carta del director (s) de Vialidad al Ministro de OO.PP. 9 de junio de 1960. Archivo Nacional, Libro 1, Folio 30, 4. DV. Secretaría No 07430.

71 "En acción combinada de las Marinas de Guerra y Mercante nacionales auxilian a zonas más afectadas". Diario El Mercurio, Santiago. Jueves 26 de mayo de 1960, Cuerpo segundo, p. 15.

72 "Concepción: El Ministro de Obras Públicas comprueba los daños causados". Diario El Mercurio, Santiago. Domingo 5 de junio de 1960, Sección Interior, P. 43.
Al conocerse la movilización en Concepción, el Gobierno decidió enviar al Sr. Luis Octavio Reyes, Visitador General de Intendencias, para coordinar las acciones y medidas necesarias para la zona. Ante esta reacción, los penquistas no dudaron en constituir un Comité Provincial de Colaboración, presidido por el rector de la Universidad de Concepción, David Stitchkin Branover, quien sugería estudiar un Plan de Rehabilitación Integrado. La finalidad de este comité era colaborar con el Gobierno, otorgándole la información y antecedentes auténticos de la tragedia $^{73}$.

Las primeras reacciones del gobierno son un poco más rápidas que en ocasiones anteriores; el Presidente Alessandri firma un decreto del Ministerio de Hacienda que permite otorgar préstamos a los damnificados, personas y firmas, de la zona afectada ${ }^{74}$. Sin embargo, un mes después de la tragedia aun no existe un proyecto de ley para la reconstrucción que esté aprobado, y el Gobierno nuevamente no logró implementar un efectivo plan de distribución del auxilio; así, los víveres, medicamentos y abrigo donado por otros países se acumulan en Valparaíso y Santiago sin llegar a destino ${ }^{75}$. Revista Vea recorrió la Aduana de Valparaíso y comprobó la acumulación de alimentos y ropas donados que nunca fueron enviados al sur. El vapor "Habana" proveniente de Cuba, el "Aconcagua" proveniente de Europa, el "Santa Inés" y el "Santa Juana" desde Estados Unidos, el chino "Stream Bank" y muchos otros provenientes de Colombia, Canadá, Perú, México e Inglaterra, habrían contribuido a llenar varios galpones de la aduana. Lamentablemente las instrucciones de las autoridades no permitían a las naves viajar directamente a los puertos del sur para entregar la ayuda, sino que todo

\footnotetext{
73 Reportaje "Concepción: Todos nos postergaron". Revista Ercilla № 1307, p. 9. Miércoles 8 de junio de 1960.

74 "Aprobado el otorgamiento de préstamos bancarios para los damnificados de las provincias afectadas". Diario El Mercurio, Santiago. Viernes 3 de junio de 1960, Cuerpo primero, P. 1.

75 Reportaje "Necesitamos 200 mil frazadas". Revista Vea $\mathrm{N}^{\circ} 1105$, p. 8-9. Jueves 30 de junio de 1960.
} 
debía pasar primero y registrarse en el puerto de Valparaíso ${ }^{76}$.

Las pérdidas generadas por los dos terremotos en Concepción ascendían a 350 millones de dólares, $40 \%$ de las viviendas destruidas, 150 mil personas sin hogar. Aún no se construían las viviendas de emergencia necesarias, el doble discurso del Gobierno sobre las medidas adoptadas se hace visible en terreno, se le da a las autoridades el apodo de los "hombres sin novedad" que con una sonrisa declaran en Santiago que todo marcha bien en la zona. "La Corporación de la Vivienda ha resultado ser un gran embudo con una enorme boca donde se recibe toda clase de peticiones pero con una salida muy pequeña"77. Mientras en el Congreso todavía no se discutía ningún presupuesto, los estudiantes de la Universidad de Concepción formaron la agrupación "Voluntarios del Techo", con la finalidad de agrupar jóvenes para la construcción de viviendas. La primera misión fue levantar 250 casas de dos piezas en un plazo de 4 días sobre un terreno de propiedad del Servicio Nacional de Salud ${ }^{78}$. El director de dicha institución despachó un "tren sanitario encargado de recorrer la provincia, llevando vacunas, medicamentos, leche en polvo y algunos médicos, además de estudiantes de medicina, practicantes y auxiliares sanitarios $^{79}$. Ante la cantidad de funcionarios y alumnos de la Universidad que quedaron sin techo, el rector planteó al Gobierno la siguiente solución: la universidad se encargaría de la construcción de más de 70 viviendas para acoger al personal universitario en el fundo Andalién, así como de la construcción de cabañas para albergar a los 830 estudiantes que no tenían albergue. Esta iniciativa tendría un costo total de 400 millones de

${ }^{76}$ Reportaje "Mientras los damnificados del sur claman por un pedazo de pan, la aduana de Valparaíso continúa atochada de alimentos". Revista Vea $\mathrm{N}^{\circ}$ 1107, p. 10-11. Jueves 14 de julio de 1960.

77 Reportaje "Se olvidaron de Concepción". Revista Vea $\mathrm{N}^{\circ} 1105$, p. 24-25. Jueves 30 de junio de 1960.

78 "Concepción: En pleno desarrollo los trabajos para levantar 250 casas en 4 días". Diario El Mercurio, Santiago. Domingo 29 de mayo de 1960, Interior, p. 28.

79 "Concepción: Excepcional planificación ha dado el SNS a su labor en la provincia". Diario El Mercurio, Santiago. Lunes 30 de mayo de 1960, Interior, p. 24. pesos, lo cual proponía financiar a través de un proyecto de ley que permitiera gravar los premios gordos de la Polla y la Lotería en un $10 \%$ por un período de 5 años $^{80}$. Finalmente se evacuaron los campamentos improvisados al interior del Palacio de Tribunales de Concepción gracias a la construcción de pabellones habitacionales realizados por la CORVI en Huachipato y que darían albergue a 2 mil familias. Sin embargo quedaban aún muchos problemas de vivienda por resolver: ciudadelas de miseria por evacuar, gente que vivía en vagones de ferrocarriles fuera de servicio y otras situaciones de gran precariedad ${ }^{81}$.

Los 100 millones de dólares recaudados por vía fiscal eran insuficientes para paliar la tragedia, por lo que se autorizó al gobierno endeudarse por 500 millones de dólares más, esto considerando que en esa época las exportaciones de la gran minería equivalían solo a 160 millones de dólares (Lagos, 2011). Por su parte, el Banco de Exportación e Importación aprobó un crédito de 10 millones de dólares para las labores de reconstrucción del Gobierno chileno ${ }^{82}$.

Recién el 31 de junio el Gobierno envió un proyecto de ley al Congreso, el cual sería aprobado en octubre de ese mismo año. En resumen, el proyecto planteaba medidas tributarias para recaudar $150 \mathrm{mil}$ millones de escudos, lo que sumado a la ayuda de 500 mil millones de escudos prestados por el exterior, conformarían la gran caja de la reconstrucción ${ }^{83}$. La Comisión de Hacienda de la Cámara de Diputados suprimió proyecto del Gobierno disminuyendo en 100 millones de escudos el rendimiento tributario, pero aumentó el impuesto a las compraventas y determinó la recolección del 1\% de los sueldos

\footnotetext{
80 "Concepción: Universidad penquista solucionará sus propios problemas habitacionales". Diario El Mercurio, Santiago. Martes 31 de mayo de 1960, Interior, p. 23.

81 Reportaje "Desaparecen los tugurios de Concepción". Revista Vea No1107, p. 24-25 Jueves 14 de julio de 1960.

82 "Consejo de la OEA convocó a sesión de emergencia para tratar ayuda a Chile". Diario El Mercurio, Santiago. Sábado 28 de mayo de 1960, Cuerpo primero, p. 1.

83 Reportaje "Quienes pagan la reconstrucción". Revista Vea N¹106, p. 8-9. Jueves 7 de julio de 1960.
} 
y salarios para la CORVI. También propone un impuesto de un 15\% sobre la propaganda en radios y diarios ${ }^{84}$.

Tras largo debate, en octubre de 1960 se promulgó la Ley $\mathrm{N}^{0} 14.171$, modificando las normas y atribuciones del Ministerio de Economía para transformarlo en Ministerio de Economía, Fomento y Reconstrucción. El desglose de esta ley permitió aprobar una medida más rápida traducida en la Ley № 14.009, permitiendo otorgar préstamos de auxilio a los imponentes de algunos institutos de previsión (Lagos, 2011). Lo anterior, da cuenta de que la principal vía para la reconstrucción luego del terremoto de 1960 fue el crédito.

Otro aspecto relevante que es producto del terremoto de 1960, fue la modificación de la Ley de Seguridad Interior del Estado, entregando así al Presidente de la República la facultad de declarar Estado de Emergencia en zonas afectadas por graves desastres naturales o calamidades públicas, por una sola vez y por un plazo de hasta seis meses. Y se modificó también, por primera vez, la Ley de Donaciones para que los privados que quisieran hacer aportes para enfrentar la catástrofe, no tuvieran además que pagar impuestos por su aporte (Lagos, 2011).

En resumen, la forma por la que optó el Gobierno para financiar las necesidades de reconstrucción del país en su amplio sentido, fue principalmente el crédito, además del aumento cuantioso de una deuda externa que se financiaría vía empréstito, es decir, transfiriendo la deuda a las generaciones futuras (Lagos, 2011).

\section{Memoria y olvido: una ciudad y el diálogo consigo misma a modo de conclusión}

¿Qué va quedando en la memoria histórica y espacial de una ciudad sino sus huellas territoriales? ¿Qué papel han jugado en el devenir de la ciudad, la presencia de estos eventos catastróficos cuya frecuencia

\footnotetext{
${ }^{84}$ Reportaje "Política del Tejo Pasado actúa en la reconstrucción". Revista Vea N¹108, p. 8-9. Jueves 21 de julio de 1960.
}

y presencia es habitual en su geografía? ¿Las narrativas que acompañan estos sucesos y la manera de reaccionar institucionalmente recogen aprendizajes en términos territoriales? ¿Cómo es que estas huellas pasan a ser parte integral de los discursos y narrativas que colaboran con asumir esta condición de tensión permanente frente al desastre latente? ¿Es la reconstrucción una permanencia histórica ${ }^{85}$ en la ciudad ícono del desarrollo industrial en Chile?

Los procesos de reconstrucción, se ha podido observar, presentan interesantísimas similitudes en cuanto a acciones, discursos, dificultades, críticas y decisiones durante el siglo XX y, sabemos también ahora por la coyuntura, en el debut del segundo decenio del siglo XXI.

Pese a los avances relevantes en la institucionalidad a causa del terremoto de 1939, la creación de la CORFO es la que muestra mayor permanencia y continuidad. No es el caso de la Corporación de Reconstrucción y Auxilio, que una vez convertida en ONEMI, si bien es interesante en lo institucional, no resulta a la larga una institución que sea protagónica en materia de preparación y gestión de los desastres; ello se pone de manifiesto particularmente en esta zona donde se sabe históricamente que se mantiene cierta frecuencia y regularidad de terremotos y tsunamis, como se pudo constatar en 2010. Pese a ello, pudimos ver de manera dolorosa, no hubo capacidad de enfrentar un hecho que desde el punto de vista de nuestra geografía histórica, no representa nada novedoso ni inesperable.

\footnotetext{
85 Aun cuando hemos situado el análisis en dos sucesos recientes del siglo XX, los antecedentes preliminarmente expuestos, a modo introductorio, hablan de una condición que mirada a través de los últimos cinco siglos ha sido más o menos similar: la ciudad se funda, se construye y un terremoto, maremoto o batalla la destruye, para luego reconstruirse. Es esta condición la que queremos destacar con la noción de permanencia, o, como lo señalara Braudel, una continuidad que mirada en una perspectiva de larga duración debiera hacernos reflexionar sobre los diferentes tiempos involucrados en el modo de pensar la ciudad (Braudel, 1969).
} 
Si bien se podría observar la situación anteriormente descrita como una curiosidad, lo realmente interesante desde el punto de vista de la reflexión a la luz del trabajo aquí expuesto, es la ausencia de una memoria contenida en la ciudad en el ámbito de la acción pública, pese a la larga data de eventos catastróficos en la ciudad (Musset, 2010; Mardones y Vidal, 2001; Aliste y Almendras, 2010; Pacheco, 1997; Mazzei De Grazia y Pacheco, 1985). Es pertinente por lo mismo preguntarse por la memoria de la ciudad. O tal vez, en rigor, por el olvido de la ciudad.

Memoria y olvido parecen articularse y hacer un juego de presencia y ausencia. Pero en este juego de articulación entre memoria y olvido, lo que tenemos como respuesta es un territorio que se asoma como fruto de esta articulación. Una memoria colectiva que encuentra en el espacio un lugar de acción y concretización que le da al colectivo ese seIlo que le otorga sentido (Halbwachs, 1997). Las narrativas aquí revisadas, en diversas fuentes, tienen la virtud de llevarnos a un lugar que tiende a revisitarse cada cierto tiempo con enormes similitudes que nos deben hacer reflexionar sobre el sentido y práctica del espacio en la construcción de la ciudad.

Como señala Ricoeur (1999), memoria, imaginación, olvido y recuerdo van a marcar derroteros que nos exigen pensar el espacio. El recuerdo no es más que la representación de una ausencia irrecuperable (Ricoeur, 2004). Este espacio cuya permanencia histórica encuentra en la reconstrucción una constante, puede llevarnos a repensar el sentido de la ciudad que se quiere hacer. Aquella ciudad que se rehace y reconstruye permanentemente.

\section{Referencias Bibliográficas}

ALISTE, E. y MORENO, R. Renacer después de la tragedia: una mirada breve a la relación entre demografia y catástrofe en Chile. Revista Anales de la Universidad de Chile, Séptima serie, №1, mayo 2011.

ALISTE, E. y ALMENDRAS, A. Trayectoria territorial de la conurbación Concepción-Talcahuano: industria, asentamientos humanos y expresión espacial del desarrollo, 1950-2000.
En: PÉREZ, L. e HIDALGO, R. (editores). Concepción Metropolitano. Evolución y desafíos. Concepción: Universidad de Concepción, Serie GEO-Libros, Instituto de Geografía-PUC, 2010, p. 123-149.

BRAUDEL, F. Chili, cette folie géographique. Annales. Économies, Sociétés, Civilisations, 1948, Nº4, p. 443-446.

BRAUDEL, F. Écrits sur l'histoire. Paris: Flammarion, 1969.

ECHEÑIQUE, A. y RODRÍGUEZ, C. Historia de la Compañía de Aceros del Pacífico S.A. Huachipato: consolidación del proceso siderúrgico chileno 1905-1950. Santiago de Chile: CAP S.A. de Inversiones, 1990.

GÓNGORA, M. Ensayo histórico sobre la noción de Estado en Chile en los siglos XIX y XX. Santiago de Chile: La Ciudad, 1981

HALBWACHS, M. La mémoire collective. Paris: Albin Michel, 1997.

ILABACA, P. El riesgo de anegamiento en la llanura litoral de Concepción - Talcahuano. Proposición metodológica. Revista Geográfica de Chile Terra Australis, 1993, N³8, p. 6572.

ILABACA, P. Condiciones naturales y crecimiento urbano: caso comuna de Talcahuano. Revista Geográfica de Chile Terra Australis, 1995, N40, p. 7-29.

LAGOS, R. Terremotos: ¿Una oportunidadpara avanzar las agendas de cada gobierno? Anales de la Universidad de Chile, séptima serie, 2011, $\mathrm{N}^{\circ} 1$, p. 57-75.

LARA, H. La ciudad Mártir. A propósito del $50^{\circ}$ aniversario del terremoto del 20 de febrero de 1835 que arruinó a Concepción. Concepción: Imprenta de La Revista del Sur, 1886.

MARDONES, M. y VIDAL, C. La zonificación y evaluación de los riesgos naturales de tipo geomorfológico: un instrumento para la planificación urbana en la ciudad de Concepción. EURE, 2001, Vol. 27, № 81, p. 97-122. 
MAZZEI DE GRAZIA, L. y PACHECO, A. Historia del traslado de la ciudad de Concepción. Concepción: Ediciones de la Universidad de Concepción, 1985.

MAZZEI DE GRAZIA, L. Sociedades Comerciales e industriales y economía de Concepción 1920-1939. Santiago de Chile: Editorial Universitaria, 1990.

MUSSET, A. Vulnerabilidad social, justicia espacial y resiliencia. Concepción, Chile, entre dos terremotos (1751-1835). En: MUSSET, A. (editor). Ciudad, sociedad, justicia: un enfoque espacial y cultural. Mar del Plata: Eudem, Universidad Nacional de Mar del Plata, 2010, p. 31-64.

PACHECO, A. Historia de Concepción. Siglo XX. Concepción: Cuadernos del Bío-Bío, Universidad de Concepción - I. Municipalidad de Concepción, 1997.
PÉREZ, L. y FUENTES, P. El Plan Regulador Intercomunal de 1963 (PRIC). Inicios de la planificación metropolitana. En: PÉREZ, L. e HIDALGO, R. (editores). Concepción Metropolitano. Evolución y desafíos. Concepción: Universidad de Concepción - Serie GEO-Libros (PUC), 2010, p. 45-58.

PÉREZ, L. e HIDALGO, R. Concepción Metropolitano. Evolución y desafíos. Concepción: Universidad de Concepción - Serie GEO-Libros, Instituto de Geografía -PUC, 2010.

RICOEUR, P. La lectura del tiempo pasado: memoria y olvido. Madrid: Arrecifes, 1999.

RICOEUR, P. La memoria, la historia, el olvido. Buenos Aires: Fondo de Cultura Económica, 2004. 